\title{
Review of Polish and international guidelines on hormonal therapy in localized prostate cancer
}

\author{
Ewa Pawłowska, Jacek Jassem
}

Prostate cancer is the second most common male malignancy in Poland. We present guidelines of Polish and international oncology and urology societies on hormonal therapy for localized prostate cancer.

NOWOTWORY J Oncol 2016; 66, 5: 403-407

Key words: prostate cancer, hormonal treatment, guidelines

\section{Introduction}

Prostate cancer is the second most frequent male malignancy in Poland [1]. The incidence has increased worldwide over recent decades, mainly due to aging of the population and growing tendency for measuring the prostate-specific antigen (PSA) levels. The management of prostate cancer requires a close collaboration between urologist, clinical oncologist and radiation oncologist to choose the most suitable therapeutic strategy considering tumor stage, the patient's general health status and his individual preferences. Evidence-based therapeutic recommendations published by Polish and international societies for oncology and urology aim at improving treatment efficacy. The 5 -year survival rates for prostate cancer patients in Poland are merely $67 \%$ compared to European average of $83 \%$ [2]. The only three European Union countries with poorer outcomes are Bulgaria, Slovakia and Latvia.

Prostate cancer is primarily hormone-dependent. This article provides recommendations from the largest societies for urology and oncology on hormone therapy (HT) in localized prostate cancer. The only recommendations available in Poland in this area were published in 2013 by the Polish Society of Clinical Oncology (PTOK) [3]. This document is mainly based on the European Association of Urology (EUA) guidelines, which were later updated in 2015 [4]. Other guidelines addressed in this article are those developed in 2007 by the American Urological Association (AUA; updated in 2011) [5], last year's recommendations from the European Society for Medical Oncology (ESMO) [6], version 1.2016 of the National Comprehensive Cancer Network (NCCN) in the US [7], and the guidelines of the British National Institute for Health and Clinical Excellence (NICE) from 2014 [8].

The article refers to low, intermediate and high risk prostate cancer prognostic groups, considering the local tumor extent according to the TNM staging system, cancer grade according to the Gleason score (GS) and the highest PSA level (Tab. I).

\section{General principles of hormone therapy}

$\mathrm{HT}$ for prostate cancer aims at inhibiting the stimulatory effect of circulating male hormones on cancer cells. This may be achieved by reducing androgen secretion by surgical or pharmacological castration, or by competitive inhibition of androgens binding to their receptors by means of anti-androgen therapy. The effectiveness of $\mathrm{HT}$ in achieving castration blood levels of testosterone is judged to be $<50 \mathrm{ng} / \mathrm{dL}$ $(1.7 \mathrm{nmol} / \mathrm{L})$. The EUA is the only society that refers to general principles of HT and suggests moving the cut-off limit to $20 \mathrm{ng} / \mathrm{dL}$ ( $1 \mathrm{nmol} / \mathrm{L}$ ), which is justified by the increased sensitivity of currently used laboratory methods [4].

The main adverse reactions of HT are cardiovascular toxicity (increased risk of heart attack), sexual function (decreased libido, erectile dysfunction), increased risk of pathological fracture, fatigue, hot flushes, depressed mood and metabolic disorders (such as insulin resistance). 
Table I. Prognostic groups of patients with localised prostate cancer

\begin{tabular}{lccc}
\hline Low risk & Intermediate risk & High risk \\
\hline PSA $<10 \mathrm{ng} / \mathrm{mL}$ & PSA $10-20 \mathrm{ng} / \mathrm{mL}$ & PSA $>20 \mathrm{ng} / \mathrm{mL}$ & Any PSA \\
and GS $<7$ & or GS $=7$ & or GS $>7$ & Any GS \\
and $\mathrm{CT} 1-2 \mathrm{a}$ & or cT2b & or cT2c & cT3-4 or cN+ \\
& Localised & & Local or regional advancement \\
\hline
\end{tabular}

GS - Gleason score; PSA — prostate specific antigen

\section{Hormonal therapies in prostate cancer GnRH analogues (LHRH, luteinizing hormone releasing hormone) and others like goserelin, leuprorelin, triptorelin}

These are the most common compounds used in $\mathrm{HT}$, and are administered by subcutaneous or intramuscular injection every 1-6 months. The first dose stimulates pituitary receptors, leading to transient increase of testosterone levels, which appears after 2-3 days and lasts for about a week. Castration concentrations of testosterone are achieved in approximately $90 \%$ of patients, usually after 2-4 weeks [9]. Initial rise of testosterone level may temporally worsen the symptoms, particularly in patients with a large prostate volume (urinary retention, acute non-renal kidney damage), massive bone metastases (bone pain, spinal cord compression) or cause sudden cardiovascular events (e.g. sudden cardiac death due to hyper-coagulation).

\section{LHRH antagonists (degarelix)}

These drugs block directly LHRH receptors in the pituitary gland and immediately reduce the circulating levels of testosterone. The main drawback is that they are short-lasting forms. These compounds are recommended for induction treatment in patients with increased risks of complications following use of LHRH analogues.

\section{Anti-androgens}

These orally administered compounds are divided according to their chemical structure into steroid (cyproterone acetate) and nonsteroid (bicalutamide, flutamide, nilutamide) derivatives. The nonsteroidal types have no effect on circulating testosterone levels. Steroid derivatives penetrate the blood-brain barrier and also inhibit centrally testosterone secretion. The adverse side effects include cardiovascular toxicity and hepatotoxicity. At the start of $\mathrm{HT}$ these drugs are usually combined with LHRH analogues to reduce the severity of side effects accompanying the transient testosterone peaking. The combination of an anti-androgen and an LHRH analogue is termed complete androgen blockade (CAB).

Published recommendations provide scant information about making preferred choices of HT agents for pros- tate cancer. PTOK, NCCN and NICE all agree that using CAB should not be considered a standard treatment $[3,7,8]$. In addition, PTOK and NICE do not recommend using anti-androgens as a monotherapy [3,7]; according to the PTOK this concerns T1a-2c grades. For patients with high risk of relapse undergoing combination therapy including radiation therapy (RT) and $\mathrm{HT}$, PTOK recommends using LHRH analogs [3].

\section{Hormone therapy as the sole treatment modality}

All urology and oncology societies point out that HT alone in patients with non-metastatic prostate cancer, including patients at old age and with major medical comorbidities, should not be considered as a standard procedure [3-8].

A separate subgroup include patients who withhold consent or are ineligible for radical treatment due to comorbidities. Urology societies and ESMO recommend in this group HT to relieve troublesome symptoms, such as urinary retention $[4,5,6]$ (Tab. II). Moreover, the EUA proposes delayed HT in: asymptomatic T3-4 patients, with PSA doubling time (PSA DT) less than 12 months, with PSA over $50 \mathrm{ng} / \mathrm{mL}$, and with poorly differentiated tumour [4]. The PTOK allows HT (other than anti-androgens) in patients with cancer symptoms and with a PSA DT $<12$ months or PSA > 25-50 ng/mL [3]. The NCCN defines a group of very high risk patients, ineligible for radical treatment who may benefit from the use of HT alone by the following features: (i) T3b-4, (ii) a primary GS of 5, or (iii) total GS of $\geq 8$ in $\geq 4$ biopsy specimens [7].

In patients ineligible for radical treatment the use of $\mathrm{HT}$ alone should take into account possible adverse reactions, which may outweigh the expected benefits (AUA) [5].

Patients with pelvic lymph node metastases at presentation should receive HT in combination with RT (according to PTOK, EUA and NCCN), or as a sole modality $(\mathrm{NCCN})[3,4,7]$.

\section{Hormone therapy as an adjunct to radical prostatectomy Preoperative HT}

EAU, NCCN, PTOK, AUA do not recommend using HT before radical prostatectomy $[3,4,5,7]$. 
Table II. Indications for hormonal therapy in patients with localised prostate cancer, withholding consent or ineligible for radical treatment due to non-oncological comorbidities

\begin{tabular}{|c|c|}
\hline Society & Indications \\
\hline EUA & $\begin{array}{l}\text { - Patients with clinical symptoms } \\
\text { - Patients without clinical symptoms and: } \\
\text { - cT3-4 and } \\
\text { - PSA DT < } 12 \text { months and } \\
\text { - PSA }>50 \mathrm{ng} / \mathrm{mL} \text { and } \\
\text { - poorly differentiated grade }\end{array}$ \\
\hline AUA & Patients with clinical symptoms and locally advanced cancer or a poorly differentiated tumour \\
\hline ESMO & Patients with clinical symptoms \\
\hline PTOK & $\begin{array}{l}\text { Patients with clinical symptoms and: } \\
\text { - PSA DT }<12 \text { months or } \\
\text { - PSA }>25-50 \mathrm{ng} / \mathrm{mL}\end{array}$ \\
\hline NCCN & $\begin{array}{l}\text { - cT3b-4 or } \\
\text { - primary GS } 5 \text { or } \\
\text { — total GS } \geq 8 \text { in } \geq 4 \text { biopsy specimens }\end{array}$ \\
\hline
\end{tabular}

EUA — European Association of Urology; AUA — American Urological Association; ESMO — European Society for Medical Oncology; PTOK — Polish Society for Clinical Oncology; NCCN — National Comprehensive Cancer Network; GS — Gleason score; PSA — prostate specific antigen; PSA DT — PSA doubling time

\section{Hormone therapy after surgery (Tab. III)}

According to the PTOK, EUA, NCCN and NICE guidelines, patients after radical prostatectomy without lymph node metastases should not receive adjuvant HT, regardless of local advancement, positive margins or other unfavorable prognostic features $[3,4,7,8]$.

Whenever lymph node metastases are histologically confirmed after radical prostatectomy, the EUA and NCCN recommend routine use of $\mathrm{HT}[4,7]$. According to the EUA, treatment in this group may be deferred until PSA levels have risen in patients who underwent extended lymph node dissection (eLND), with microscopic metastases no more than two lymph nodes (without extranodal invasion) and with a postoperative PSA of $<0.1 \mathrm{ng} / \mathrm{mL}$, provided they are subjected to active surveillance [4]. PTOK guidelines recommend starting $\mathrm{HT}$ only in patients with at least two lymph nodes involved [3].

\section{Hormone therapy in combination with radiotherapy}

According to all the aforementioned guidelines, low-risk patients should receive $\mathrm{RT}$ without $\mathrm{HT}$ and intermediate-risk patients should be considered for RT combined with HT lasting for 4-6 months (Tab. IV) [3-8]. In patients selected for combined treatment, special attention should be paid towards the comorbidities which may reduce the expected benefit of systemic treatment. Apart from NICE, all societies recommend starting $\mathrm{HT}$ before RT (although the EUA also allows for both treatments to be launched simultaneously) [4] and for continuing HT during and after RT for 4-6 months [3-7]. NICE recommends using HT before, during or after the RT [8].

In patients with a significant history of medical comorbidities or in those not consenting to HT due to possible complications (e.g. sexual dysfunctions), the EUA and AUA permit the exclusive use of RT at escalated doses [4, 5]. In high risk patients (i.e. very high risk or loco-regional advancement, depending on the terminology used in the guidelines) all societies, apart from NICE, recommend combining RT with long-term HT (2-3 years) [3-7]. NICE recommends that extending the duration of $\mathrm{HT}$ for more than 6 months should be discussed with the patient [8]. EUA points out that extending $\mathrm{HT}$ for over 6 months to 2-3 years should consider patient's health status, comorbidities and any adverse prognostic factors, such as local advancement $\geq \mathrm{T} 2 \mathrm{C}, \mathrm{GS} \geq 8, \mathrm{PSA}>20 \mathrm{ng} / \mathrm{mL}$ [4]. Expected survival time

Table III. Indications for adjuvant hormonal therapy after radical prostatectomy in non-metastatic prostate cancer patients

\begin{tabular}{lcccc}
\hline Category & EUA & PTOK & NICE & NCCN \\
\hline pN0 & No HT & No HT & No HT & No HT \\
$\mathrm{pN}+$ & $\mathrm{HT}$, with deferring HT until biochemical relapse in patients post eLND, \\
with $\leq 2$ involved lymph nodes and PSA level $<0.1 \mathrm{ng} / \mathrm{mL}$ & HT if $\geq 2$ nodes & HT & \\
\hline
\end{tabular}

NICE — National Institute for Health and Clinical Excellence; eLND — extended lymph node dissection; HT — hormone therapy 
Table IV. Recommendations for combining hormone therapy with radiotherapy in patients with localised prostate cancer

\begin{tabular}{|c|c|c|c|}
\hline Society & Low risk & Intermediate risk & High risk/ local or regional advancement \\
\hline EUA & RT alone & $\begin{array}{l}\mathrm{RT}+\mathrm{HT} 4-6 \text { months } \\
\text { if no contraindications }\end{array}$ & $\begin{array}{l}\mathrm{RT}+\mathrm{HT} 2-3 \text { years } \\
\text { (if no contraindications) }\end{array}$ \\
\hline PTOK & RT alone & $\begin{array}{l}\mathrm{RT}+\mathrm{HT} \text { 4-6 months in patients with } \\
\text { unfavourable prognostic factors }\end{array}$ & $\mathrm{RT}+\mathrm{HT}$ 2-3 years \\
\hline ESMO & RT alone & $\mathrm{RT} \pm \mathrm{HT}$ 4-6 months & $\mathrm{RT}+\mathrm{HT} 2-3$ years \\
\hline NICE & RT alone & $\mathrm{RT}+\mathrm{HT} 6$ months & $\begin{array}{c}\mathrm{RT}+\mathrm{HT} \geq 6 \text { months; extension to } 3 \text { years } \\
\text { should be considered }\end{array}$ \\
\hline AUA & RT alone & $\mathrm{RT}+\mathrm{HT} 6$ months & $\mathrm{RT}+\mathrm{HT} 2-3$ years \\
\hline NCCN & RT alone & $\mathrm{RT} \pm \mathrm{HT}$ 4-6 months & $\begin{array}{c}\mathrm{RT}+\mathrm{HT} 2-3 \text { years } \\
\text { (if no contraindications) }\end{array}$ \\
\hline
\end{tabular}

RT — radiotherapy; HT — hormone therapy

and complication risk should be taken into account in elderly patients with significant comorbidities, since they may not benefit from combining RT and HT (EUA) [4].

Owing to the absence of dedicated randomized trials, special considerations apply to patients administered proton radiotherapy. Hence, this treatment should follow photon RT (EUA) [4].

\section{Hormone therapy in patients with biochemical relapse after curative local treatment (Tab. V)}

The definition of biochemical relapse after prostatectomy includes two PSA measurements of $>0.2 \mathrm{ng} / \mathrm{mL}$, with a rising trend [10], whereas biochemical relapse after radical RT is defined as increasing PSA levels by $\geq 2 \mathrm{ng} / \mathrm{mL}$ compared to the lowest post-radiotherapy levels [11].

Due to the lack of strong supporting evidence, the role of HT after curative local treatment is still a matter of debate and therapeutic decisions are based on individual/case-bycase approach [4, 7]. According to all guidelines (Tab. V), a biochemical relapse after radical prostatectomy is not an indication for immediate HT [4, 6-8]. In patients with a short PSA DT and long expected survival, the NCCN guidelines suggest considering early launching of intermittent $\mathrm{HT}$ [7]. The EUA does not recommend using $\mathrm{HT}$ in asymptomatic patients and in patients with a long (> 12 months) PSA DT [4]. According to the NCCN, HT is indicated in patients with a high probability of distant metastases, irrespective of whether salvage RT is used [7]. The NICE and ESMO guidelines include three indications for administering HT after radical prostatectomy: symptomatic disease, confirmed distant metastases and a PSA DT $<3$ months $[6,8]$.

$\mathrm{HT}$ at biochemical relapse after radical RT is also indicated in patients not eligible to salvage treatment (EUA) [4]. EUA and ESMO suggest using an intermittent regimen for such patients $[4,6]$, whilst the NCCN recommends watchful waiting or immediate application of $\mathrm{HT}$, depending on individual risk of relapse [7].

\section{Conclusions}

The presented evidence-based guidelines demonstrate relative uniformity regarding the most important indications for the use of HT in patients with localized prostate cancer. Their widespread implementation might improve treatment outcomes of this entity in Poland.

Table V. Considerable indications for hormone therapy in patients with biochemical relapse after radical treatment

\begin{tabular}{ll}
\hline Society & Indications \\
\hline EUA & - PSA DT $<12$ months - to be considered \\
& - No possibility of salvage treatment after radical RT, considering risk factor \\
NCCN & - Short PSA doubling time (PSA DT) and long expected survival \\
& - High risk of distant metastases \\
NICE & - Symptomatic local progression \\
& - PSA DT $\leq 3$ months \\
ESMO & - Symptomatic local progression \\
& - PSA DT $\leq 3$ months
\end{tabular}

PSA — prostate specific antigen; PSA DT — PSA doubling time; RT — radiotherapy 
Conflicts of interest: EP declares no conflict of interest. $\mathrm{J} \mathrm{J}$ is an advisory committee member and lecturer for: Amgen, AstraZeneca, BMS, Boehringer, Lilly, Pfizer, Roche, Merck and Novartis as well as received travel support from Roche, Novartis and Boehringer.

\section{Acknowledgment}

The authors thank Ms Claudia Wiewiora for linguistic check-up.

\section{Ewa Pawłowska, MD}

Department of Oncology and Radiotherapy

Medical University of Gdańsk, Poland

Dębinki 7, 80-952 Gdańsk, Poland

e-mail:ewanowak@gumed.edu.pl

Received:12 May 2016

Accepted: 29 Jun 2016

\section{References}

1. Wojciechowska U, Didkowska J. Zachorowania i zgony na nowotwory złośliwe w Polsce. Centrum Onkologii — Instytut im. Marii Skłodowskiej-Curie: Krajowy Rejestr Nowotworów. http://onkologia.org.pl/raporty/ /accessed 11/01/2016.
2. Trama A, Foschi R, Larrañaga $\mathrm{N}$ et al. Survival of male genital cancers (prostate, testis and penis) in Europe 1999-2007: Results from the EUROCARE-5 study. Eur J Cancer, 2015; 51: 2206-2216.

3. http://www.onkologia.zalecenia.med.pl/pdf/PTOK_2013_07_Nowotwory\%20ukladu\%20 moczowo-plciowego.pdf.

4. http://uroweb.org/wp-content/uploads/EAU-Guidelines-Prostate-Cancer-2015-v2.pdf.

5. http://www.auanet.org/common/pdf/education/clinical-guidance/ /Prostate-Cancer.pdf

6. https://annonc.oxfordjournals.org/content/26/suppl_5/v69.full. pdf+html.

7. http://www.nccn.org/professionals/physician_gls/pdf/prostate.pdf.

8. http://www.nice.org.uk/guidance/cg175/chapter/1-recommendations.

9. Morote J, Planas J, Salvador C et al. Individual variations of serum testosterone in patients with prostate cancer receiving androgen deprivation therapy. BJU Int 2009; 103: 332-335.

10. Cookson MS, Aus G, Burnett AL et al. Variation in the definition of biochemical recurrence in patients treated for localized prostate cancer: the American Urological Association Prostate Guidelines for Localized Prostate Cancer Update Panel report and recommendations for a standard in the reporting of surgical outcomes. J Urol 2007; 177: 540-545.

11. Roach M 3rd, Hanks G, Thames $H$ Jr et al. Defining biochemical failure following radiotherapy with or without hormonal therapy in men with clinically localized prostate cancer: recommendations of the RTOG-ASTRO Phoenix Consensus Conference. Int J Radiat Oncol Biol Phys 2006; 65: 965-974. 